Research Article

\title{
Effects of Soil Conservation Practice and Crop Rotation on Selected Soil Physicochemical Properties: The Case of Dembecha District, Northwestern Ethiopia
}

\author{
Melkamu Degu $\mathbb{D}^{1},{ }^{1}$ Asmare Melese $\mathbb{D},{ }^{2}$ and Wondwosen Tena ${ }^{2}$ \\ ${ }^{1}$ Department of Natural Resource Management, College of Agriculture and Natural Resource Sciences, \\ Debre Berhan University, Ethiopia \\ ${ }^{2}$ Department of Plant Science, College of Agriculture and Natural Resource Sciences, Debre Berhan University, Ethiopia \\ Correspondence should be addressed to Melkamu Degu; melkishdegu075@gmail.com and \\ Asmare Melese; asmaremelese@gmail.com
}

Received 11 January 2019; Accepted 7 April 2019; Published 2 May 2019

Academic Editor: Marco Trevisan

Copyright (C) 2019 Melkamu Degu et al. This is an open access article distributed under the Creative Commons Attribution License, which permits unrestricted use, distribution, and reproduction in any medium, provided the original work is properly cited.

\begin{abstract}
Crop rotation systems especially dominated by cereals (maize and wheat) are intimately linked to soil properties. The objective of the study was to investigate the effect of crop rotations and conservation practice on selected soil physicochemical properties in northwestern part of Ethiopia. Soil samples $(0-20 \mathrm{~cm}$ depth) were collected from seven crop rotations with conservation practice and adjacent fields without any conservation measure in three replications. A total of forty-two composite samples were used for analysis by using SAS software. The land rotated with maize-wheat-faba bean exhibited significantly higher mean bulk density $\left(1.06 \mathrm{~g} / \mathrm{cm}^{3}\right)$ than the land rotated with other crops (i.e., ranging from 1.02 to $\left.1.04 \mathrm{~g} / \mathrm{cm}^{3}\right)$. Mean values of $\mathrm{pH}(5.34,4.98$, and 5.4), Ex. acidity $\left(2.03,2.53\right.$, and $\left.2.16 \mathrm{cmol}_{\mathrm{c}} / \mathrm{kg}\right)$, soil OM $(4.53 \%, 5.12 \%$, and $5.02 \%)$, CEC $\left(45.17,48.03\right.$, and $\left.49.47 \mathrm{cmol}_{\mathrm{c}} / \mathrm{kg}\right)$, TN $(0.23$, 0.25 , and $0.27 \%)$, Av.P (10.21, 7.23, and $7.95 \mathrm{ppm})$, and $\mathrm{C}: \mathrm{N}$ ratio $(11.18,11.95$, and 10.8) were recorded under rotations with continuous maize, maize-pepper-pepper, and maize-faba bean-pepper, respectively. Mean values of pH (5.34 and 4.97), Av.P (9.51 and $6.53 \mathrm{ppm}), \mathrm{CEC}\left(48.3\right.$ and $\left.46.87 \mathrm{cmol}_{\mathrm{C}} / \mathrm{kg}\right)$, and Ex. acidity $\left(2.5\right.$ and $\left.2.85 \mathrm{cmol}_{\mathcal{C}} / \mathrm{kg}\right)$ were also recorded under conserved and unconserved farmlands, respectively. Considering the interaction effect of crop rotations by conservation practice, all studied parameters, except bulk density, CEC, and C: $\mathrm{N}$ ratio, were significantly $(p<0.05)$ affected. The findings indicate that although continuous maize showed good content of available $\mathrm{P}$ and low exchangeable acidity, it will deplete particular nutrients; therefore, maize-pepper-pepper, maize-wheat-faba bean, and maize-faba bean-pepper recorded a slight trend of good values in studied soil physicochemical properties compared to other rotations. A critical study on such type of issue should be carried out over a longer period of time in order to announce detailed understanding about response of soil property to crop rotations to the community.
\end{abstract}

\section{Introduction}

Ethiopia is one of the well-endowed countries in subSaharan Africa in terms of natural resources [1]. However, natural resource degradation in Ethiopia has been going on for centuries [2]. The major causes of land degradation in Ethiopia are rapid population growth, severe soil loss, deforestation, low vegetative cover and unbalanced crop, and livestock production [3].

Ethiopia is reported to have the highest rates of soil nutrient depletion through soil erosion in sub-Saharan Africa.
Soil erosion is a severe problem in the highlands of Ethiopia, especially in Amhara Region [4]. Sheet, rill, and gully erosion are commonly observed in the high rainfall areas of East and West Gojjam Zone where Nitisols are dominant [5]. These types of erosion carry away the fine soil particles of the most fertile topsoil and organic matter and affect associate soil properties [6]. The rate of soil erosion losses, 130 tons $\cdot \mathrm{ha}^{-1} \cdot \mathrm{yr}^{-1}$ for cultivated fields and 35 tons $\cdot \mathrm{ha}^{-1} \mathrm{yr}^{-1}$ average for all land in the highland areas, was estimated to be even one of the highest in Africa [7]. The field level nutrient balances on Nitisols reported from southern Ethiopia $(-102$, 
-45 , and $-67 \mathrm{~kg}$ of $\mathrm{N}, \mathrm{P}$, and $\mathrm{K} \cdot \mathrm{ha}^{-1}$ ) are even more threatening [8].

Soil conservation in Ethiopia is considered to be top priority, which is the long-term objective of the agricultural development program [9]. A great deal of attention has been paid to soil management practices that promote sustainable soil quality and productivity [10].

Crop rotation is the practice of cultivating different sequences of crops on the same plot of land. It can have a major impact on soil health, due to emerging soil ecological interactions and processes that occur with time. It is a beneficial approach to reduce soil erosion, balance, manage and improve the fertility of the soil, improve soil structure, avoid excessive depletion of soil nutrients, and control weeds, pest, and diseases [11].

Physical soil and water conservation structures are designed to intercept and reduce runoff velocity, pond and store runoff water, convey runoff at nonerosive power, trap sediment and nutrients, promote formation of natural terraces over time, prevent flooding of neighboring lands, reduce sedimentation of waterways, streams, and rivers, and improve soil properties or land productivity [12].

Assessment of important soil physical, chemical, and biological properties and their responses to changes in land management is necessary to apply appropriate agricultural technologies and effective design of soil fertility management techniques [13]. In the area under the present study, there is long-lasting intensive cultivation. To reverse the problem, soil and water conservation practices are an influential tool which enables the productive potential of the soil.

Farmers in the study area have been practicing common crop rotations, and currently, physical soil and water conservation structures were started in order to improve their land productivity through erosion reduction. Such traditional crop rotation practices have not been ignored or underestimated by development agents, researchers, soil conservationists, and government staff. Currently, other physical soil and water conservation measures such as soil bunds have been practiced at Dembecha District as effective measures for continued soil problems. However, apart from monitoring and evaluation reports, no substantive studies made on short- and long-term effects on soil properties. Therefore, the objective of the study was to evaluate the short-term cumulative effects of three-year crop rotation and soil conservation measure on selected soil physicochemical properties.

\section{Materials and Methods}

2.1. Description of the Study Area. The study was conducted in 2018 on farmers' fields at the middle part of Dembecha District, West Gojjam Zone of Amhara National Regional State, Ethiopia. It is situated $348 \mathrm{~km}$ Northwest Addis Ababa, $205 \mathrm{~km}$ from regional state, Bahir Dar and about $30 \mathrm{~km}$ distance from Finote-Selam (the West Gojjam Zone Capital). The district includes 25 rural and 4 urban kebeles with an area of 97,926 ha and estimated total population of 151,023 (Central Statistical Agency, 2015).
Geographically, it is positioned between $37^{\circ} 11^{\prime} 00^{\prime \prime}$ $37^{\circ} 38^{\prime} 51^{\prime \prime} \mathrm{E}$ and $10^{\circ} 19^{\prime} 62^{\prime \prime}-10^{\circ} 19^{\prime} 21^{\prime \prime} \mathrm{N}$ with elevation of 1021-2516 meters above sea level (masl) (Figure 1). Topographically, the area is characterized by $60 \%$ flat, $34 \%$ mountainous, and $6 \%$ valley with percentage of soil type of $65 \%$ red, $25 \%$ blue, and $10 \%$ black. Generally, the climate is dry subhumid with a unimodal rainy season from June to October and a mean annual rainfall ranging from 1182.3 to $1880.9 \mathrm{~mm}$. Most of the district is covered by Alisols.

The other major soils include Nitisols, Cambisols, Fluvisols, Leptosols, and Vertisols [14]. Therefore, accordingly, the general soil natures in the specific study area were Nitisols and Alisols [14].

2.2. Soil and Water Conservation Practices in the Study Area. Currently, the local community has been implementing different techniques to protect their farmland from erosion and to enhance its fertility beyond commonly adopted crop rotations. In the year 2015, level soil bund was constructed on 62,000 ha of land, $42.2 \mathrm{~km}$ diversion ditches, 18,761 soil microtrench, 8.4 ha hillside terrace, etc., as a soil and water conservation measure. Asteboj Kebele is one of the 25 rural kebeles found in Dembecha District. The study took into consideration 3000 ha of farmland at Asteboj Kebele, on which level soil bund was constructed since 2015 . Besides the commonly adopted crop rotation techniques, physical soil and water conservation measure, mainly level soil bund, has been practiced every year in this specific area.

2.3. Farming System. All farmers have been using traditional and rain fed subsistence-oriented farming system. The common farming practices in the area are intensive and continuous cultivation, free grazing, and overgrazing. Cultivation is mostly practicing on flat lands. Among the crops, maize (Zea mays L.), wheat (Triticum aestivum L.), and pepper (Capsicum annuum L.) with few faba bean (Vicia faba L.) seem to be very promising for many of the farmers in this area.

The major crop rotations practiced in the area are from cereal to cereal (maize and wheat) and from cereals to noncereal crops (rotation between maize, wheat, pepper, and faba bean). However, continuous maize or maize after maize is also still practiced on many farms that have a large demand for maize silage and want to drink "Tella" in the year round.

The local people plowed the farmland many times to make the land more suitable for crop production through conventional tillage practices. But, the number of plowing repetition varies from crop to crop. For example, when they want to produce maize and wheat, they plow the farmland for 7 to 8 times and to grow pepper farmers, plow more than this and special management activities like per week weeding and digging is common after transplanting.

Nitrogen $(\mathrm{N})$ and phosphorus $(\mathrm{P})$ in the form of diammonium phosphate (DAP) and urea were the major fertilizers widely applied according to farmer's recommendation rate. However, farmers have started to apply other blended fertilizers like NPS and NPSB since 2017. Each 


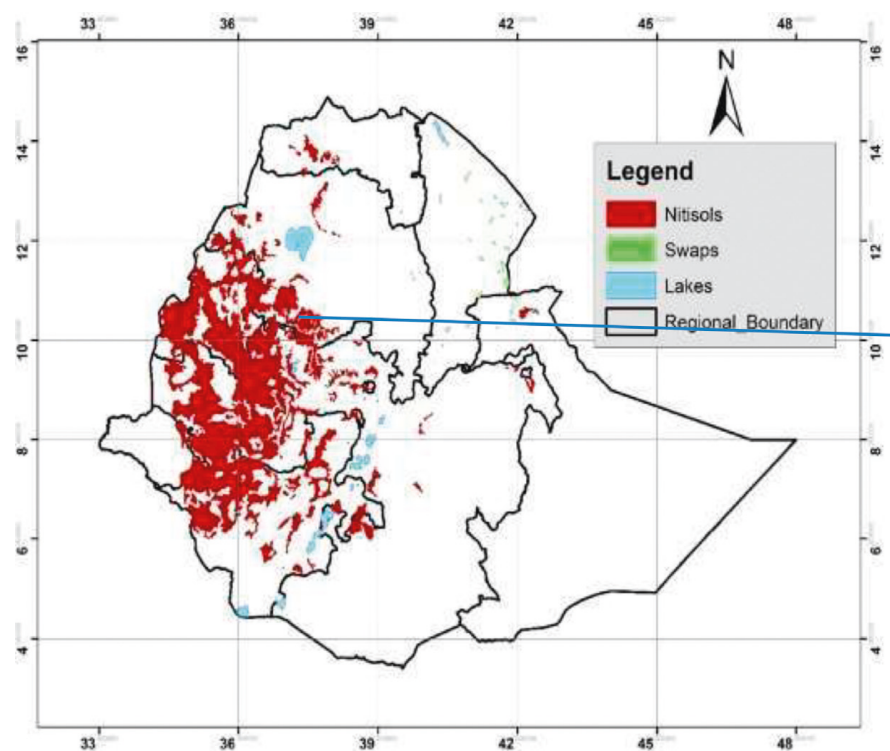

(a)

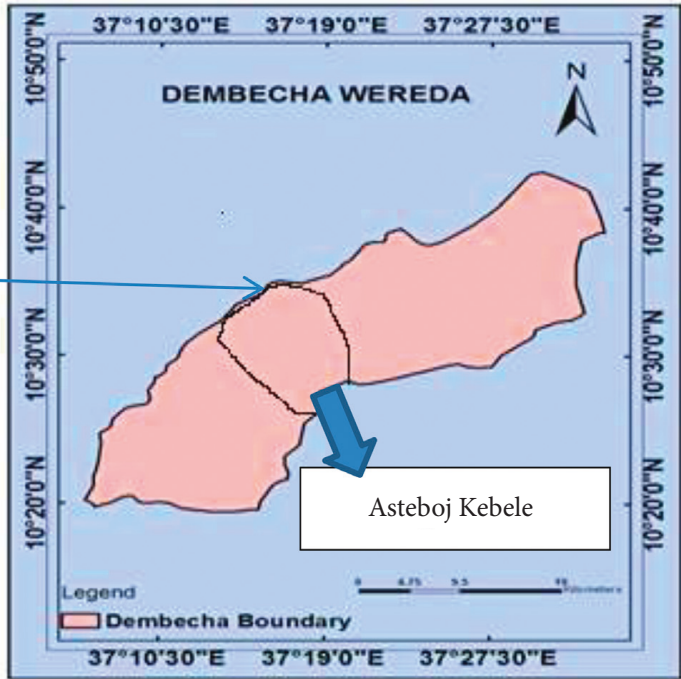

(b)

Figure 1: Distribution of (a) Nitisols in the Ethiopian highlands and location map of the study area within (b) Dembecha District.

form of soil fertilizer $200 \mathrm{~kg} / \mathrm{ha}$ has been required in two splits. Exceptionally, to grow wheat, farmers are going to apply a mixture of DAP and urea fertilizer at the time of sowing, while in all cases, urea is applied some weeks after planting at the standing crop. Diammonium phosphate (DAP), NPS, or NPSB is going to be applied by furrow method alongside seed for maize and wheat during transplanting of the seedling (i.e., for pepper). In the case of urea fertilizer to the standing crop, side-dressing or strip application methods are applied for maize and pepper crops and foliar application for wheat. An interesting concept here is the following of pepper or faba bean growing on a particular land; there is a reduction on required fertilizer application from the common traditional standards to the next crop growth.

After harvesting the crop, about $15 \mathrm{~cm}$ height of wheat straw and all biomass parts of pepper crop except fruit, is left on the farmland. However, all parts of maize crop residue go to home, used as half part (the above) is available to oxen fodder and the bottom is used as fuel wood, mainly baking of "Enjera" and bread.

2.4. Traditional Practices. Farmers in the study area have awareness about some traditional soil and water conservation practices as a measure to decrease seed loss, particularly those cereals of fine seed, such as teff, protect soil from erosion, and decrease water logging problems. Such traditional practices are the most effective mechanism, adopted by the local community, to protect and recover the fertility and productivity of the farmlands in the study communities. Contour farming is one of the traditional practices of cultivating the land along the contour line in order to reduce the runoff on a steep sloping area. It is used alone or in combination with other conservation measures such as cut-off drains. Cut-off drains (Traditional Waterways), locally known as "Booi," is also the other traditional physical structure commonly constructed by digging the soil deep in order to divert the runoff before reaching the farmland. Furthermore, traditional ditches ("feses") are widely practiced at household-level structural soil conservation measures in the study area. These structures are built with ox plow and are deeper than the normal furrow.

2.5. Site Selection. From 25 rural kebeles found in Dembecha District, Asteboj Kebele was purposively selected because such crop rotation practices are common, and currently level soil bund has been started as a soil and water conservation practice. A preliminary survey was conducted in order to get better information about the general overview of study area and the data to be collected.

2.6. Treatments and Sampling Design. The experiment involves a two-factor treatment (seven crop rotations and conservation practice), which is common practice in the area nowadays. Rotation treatments were examined in two ways (i.e., farmlands only crop rotation and with physical soil and water conservation) in randomized complete block design (RCBD) with three replications. A total of 42 soil samples were taken from the seven crop rotations (maize-maizemaize, maize-wheat-maize, maize-wheat-wheat, maizewheat-pepper, maize-pepper-pepper, maize-wheat-faba bean, and maize-faba bean-pepper) with and without conservation practice with three replications.

2.7. Soil Samples Collection. The selection of the appropriate sampling techniques was based on the unbiasedness and resource-fullness of the samples in line with the objectives of the study. Before the experiment was started, a field survey was conducted in consultation with key informants, local 
development agents, and kebele leaders to locate representative sampling fields.

Based on last three years' cropping pattern already practiced by the local farmers, seven types of crop rotation were present. Parallel to each crop rotation without any conservation practice, adjacent farmlands treated with soil bunds that had a similar slope, nature of soil formation, histories, and managements are identified. From each representative experimental farmland, 14 soil samples from depth of 0-20 cm were taken (by using core a sampler have $5 \mathrm{~cm}$ diameter and $5 \mathrm{~cm}$ height) using an " $\mathrm{X}$ " sampling technique [15]. Then, the collected soil samples from each farmland were mixed thoroughly in a clean plastic bucket to form a composite sample for analysis of target soil properties. Parallel to each sampling, undisturbed soil by using core sampler samples were taken to determine the bulk density of the soil.

2.8. Soil Samples Preparation and Analysis. The composite soil samples (depth of $0-20 \mathrm{~cm}$ ) were air-dried and grounded to pass through a $2 \mathrm{~mm}$ sieve size in preparation for the analysis of selected soil physicochemical properties. However, the soil samples for determination of organic carbon and total nitrogen were again grounded to pass a $0.5 \mathrm{~mm}$ sieve. Laboratory analysis of the soil samples was completed at the soil testing laboratory of Debre Berhan Agricultural Research Center following standard laboratory procedures.

Soil textural analysis was determined by the Bouyoucus hydrometer method [16]. Soil textural class names were assigned based on the relative contents of the percent sand, silt, and clay separates using the soil textural triangle of the soil taxonomy [17]. For bulk density calculations, undisturbed oven-dried soil weights at $105^{\circ} \mathrm{C}$ for 24 hours were recorded and the oven dry mass was divided to the total volume [18].

Soil $\mathrm{pH}$ was determined using a $\mathrm{pH}$ meter with a suspension of $1: 2.5$ soils to water ratio using a glass-calomel electrode [19]. Wet digestion method was used to determine soil carbon content with reduction of potassium dichromate by organic carbon compound and determined by reduction of potassium dichromate by oxidation reduction titration with ferrous ammonium sulfate; then soil OM contents are estimate from the OC content by multiplying with 1.724 [20]. Total N content was determined using the Kjeldahl digestion, distillation, and titration methods [21]. The soil available $\mathrm{P}$ content was also analyzed by $0.5 \mathrm{M}$ sodium bicarbonate extraction solution ( $\mathrm{pH}$ 8.5) method of Olsen as described by Van Reeuwijk [19].

Exchangeable cations and CEC $\left(\mathrm{cmol}_{\mathrm{c}} / \mathrm{kg}\right)$ were determined by $\mathrm{NH}_{4} \mathrm{OAC}$ method at $\mathrm{pH}$ 7. In the leachate, exchangeable $\mathrm{Ca}^{2+}$ and $\mathrm{Mg}^{2+}$ were determined using Atomic Absorption Spectrophotometer (AAS) and $\mathrm{Na}^{+}$ and $\mathrm{K}^{+}$by flame photometer as outlined by Van Reeuwijk [19]. Exchangeable acidity was determined by saturating the soil samples with potassium chloride solution and titrated with sodium hydroxide as described by Mclean [22].
2.9. Data Analysis. The laboratory data obtained from the soil sample were statistically analyzed by using the GLM procedure with two-way analysis of variance (ANOVA) by using SAS version 9.4 to examine the effects of treatments on the selected soil properties. Mean difference among treatments was adjusted by Duncan's multiple range test. Correlation was used to indicate the strength of association between soil parameters [23].

\section{Results and Discussion}

The results obtained from the analysis of variance indicated that crop rotation had significant $(p<0.05)$ effects on all predetermined parameters. However, conservation practice does not affect all the three soil separates. Also, all studied soil properties except bulk density, cation exchange capacity, and carbon to nitrogen ratio were also significantly $(p<0.05)$ affected by the interaction of crop rotation and conservation practice.

\subsection{Soil Physical Properties}

3.1.1. Bulk Density (BD). A significant $(p<0.05)$ effect in the mean value of bulk density was observed under all crop rotations and conservation practice (Table 1). However, the interaction of crop rotation by conservation practice did not significantly $(p>0.05)$ affect bulk density. There was a slight difference in mean values of bulk density among crop rotations $\left(0.99-1.06 \mathrm{~g} / \mathrm{cm}^{3}\right)$. The land rotated with maizewheat-faba bean exhibited relatively high mean bulk density $\left(1.06 \mathrm{~g} / \mathrm{cm}^{3}\right)$ than the other crop rotations (i.e., ranged from $0.99-1.04 \mathrm{~g} / \mathrm{cm}^{3}$ ) (Table 1). All the values of bulk density were below the critical values for agricultural lands $\left(1.4 \mathrm{~g} / \mathrm{cm}^{3}\right)$ as suggested by Hillel [24].

"The reason in high bulk density under maize-wheatfaba bean might be due to farmlands left for growing of faba bean are not going to be plowed more than two or three times a year (low tillage intensity), which results in little pore space due to minimum soil disturbance". The result was in line with the study conducted by Halvorson et al. [25] who reported that the increased bulk density under no or minimum tillage ascribed to the lack of mechanical fracturing of the soil.

Low bulk densities of $0.99 \mathrm{~g} / \mathrm{cm}^{3}$ were recorded on soil samples taken from maize-faba bean-pepper. Besides high organic-matter residue from pepper crop, a reduction in bulk density under maize-faba bean-pepper might be less compaction likely due to plowing of the land many times to plant pepper seedling and per week mechanical disturbance of the land as a management activity of the crop.

Considering main effects of conservation practice, farmlands conserved, and unconserved with soil bund showed mean value of bulk density 1.01 and $1.04 \mathrm{~g} / \mathrm{cm}^{3}$, respectively (Table 1 ). The result was in line with a previous study conducted by Mulugeta and Stahr [26], in south Gondar, northwestern highlands of Ethiopia, who observed that bulk density of the topsoil sampled in conserved lands exhibited lower bulk density than the unconserved lands. The reason might be the presence of higher organic matter 
TABLE 1: Mean values of soil bulk density and the three soil separates percentage in response to crop rotation treatments and conservation practice.

\begin{tabular}{lcccc}
\hline Treatment & $\begin{array}{c}\text { BD } \\
\left(\mathrm{g} / \mathrm{cm}^{3}\right)\end{array}$ & Sand & $\begin{array}{c}\text { Silt } \\
(\%)\end{array}$ & Clay \\
\hline Crop rotation (CR) & & & & \\
MMM & $1.02^{\mathrm{b}}$ & $19.67^{\mathrm{a}}$ & $19.67^{\mathrm{c}}$ & $60.67^{\mathrm{e}}$ \\
MWM & $1.02^{\mathrm{b}}$ & $14^{\mathrm{b}}$ & $16.83^{\mathrm{d}}$ & $68.83^{\mathrm{c}}$ \\
MWW & $1.04^{\mathrm{b}}$ & $14^{\mathrm{b}}$ & $21.17^{\mathrm{b}}$ & $64.83^{\mathrm{d}}$ \\
MWP & $1.03^{\mathrm{b}}$ & $8^{\mathrm{d}}$ & $18.17^{\mathrm{d}}$ & $73.83^{\mathrm{b}}$ \\
MPP & $1.03^{\mathrm{b}}$ & $6.67^{\mathrm{d}}$ & $17^{\mathrm{d}}$ & $76.33^{\mathrm{a}}$ \\
MWFb & $1.06^{\mathrm{a}}$ & $11^{\mathrm{c}}$ & $24.83^{\mathrm{a}}$ & $65.67^{\mathrm{d}}$ \\
MFbP & $0.99^{\mathrm{c}}$ & $11.83^{\mathrm{c}}$ & $18.17^{\mathrm{d}}$ & $71^{\mathrm{c}}$ \\
\hline Con. practice (CP) & & & & \\
Conserved & $1.01^{\mathrm{b}}$ & $11.8^{\mathrm{a}}$ & $19.43^{\mathrm{a}}$ & $69.14^{\mathrm{a}}$ \\
Unconserved & $1.04^{\mathrm{a}}$ & $12.47^{\mathrm{a}}$ & $19.38^{\mathrm{a}}$ & $68.33^{\mathrm{a}}$ \\
CR & $*^{*}$ & $* * *$ & $* * *$ & $* * *$ \\
CP & $* * *$ & $\mathrm{NS}$ & $\mathrm{NS}$ & $\mathrm{NS}$ \\
CV (\%) & 1.91 & 11.0 & 65.81 & 2.78 \\
\hline
\end{tabular}

Means followed by the same letter(s) within the same treatment group are statistically the same and showed no significant difference by DMRT $(p<0.05){ }^{*},{ }^{* *}$, and ${ }^{* * *}$ mean significant differences at $0.05,0.01$, and 0.001 probability levels, respectively, and NS means nonsignificant differences. mmm, mwm, mww, mwp, mpp, mwfb, and mfbp refer to continuous maize-maize-wheat-maize, maize-wheat-wheat, maize-wheat-pepper, maize-pepper-pepper, maize-wheat-faba bean, and maize-faba bean-pepper, respectively.

and decay of plant residues resulted from conservation measure. The result was also supported by the study of Abay et al. [27] who indicated the effects physical soil and water conservation measures on selected soil properties in central and northwestern highlands of Ethiopia.

3.1.2. Soil Texture. Soil texture or soil separates were significantly $(p<0.05)$ affected by crop rotation and their interaction (Tables 1 and 2). The soil textural class in the study area was clay with high mean value of clay content ranging from minimum $60.67 \%$ under continuous maize to maximum $76.33 \%$ under maize-pepper-pepper followed by maize-wheat-pepper $73.83 \%$ across all crop rotations (Table 1).

Soils taken from continuous maize showed relatively high percentage of sand particles (19.67). The reason might be due to plowing of the land at the standing crop, traditionally called "madager" mainly as a management of standing crop. Such activities may create favorable conditions for downward movement of clay particles to subsurface through percolating water; then, time-based coarser particles remain at the surface.

Even if the textural class of all treatments was clay, the relatively high clay content under the maize-wheat-pepper $(78.35 \%)$ and maize-pepper-pepper $(76.33 \%)$ rotation were likely due exposed of clay soil separates through per week special managements of such farm fields like weeding and digging until harvesting season is reach. These management activities could initiate continuous erosion of surface soil layer and consequently more clay soil particle will be exposed to the surface. The result was also in line with the study
Jamala and Oke [28] who reported that soil texture is intrinsic soil property, but intensive cultivation could contribute to the variations in particle size distribution at the surface horizon of cultivated land.

Considering the main effect of conservation practice, percentage of clay under conserved and unconserved farmlands was $69.14 \%$ and $68.33 \%$, respectively. The relatively high clay content in the conserved farmlands could be due to continuous deposition of arriving sediments, which led to exposure build-up of the clay-rich soil (Table 1). This result was in-contrast with the study conducted by Mulugeta and Karl [26] who indicated that lands conserved by physical soil and water conservation measures revealed a topsoil texture of clay loam, whereas the nonconserved land was relatively dominated by clay. However, the results of the study were somewhat comparable with the findings of Kebede et al. [29] who reported that soil bunds aged four year showed that relatively greater clay content was observed as compared to its adjacent nonconserved crop lands. Similar result was reported by Daniel et al. [30], indicating that all landscape positions with conservation practice showed higher clay content than unconserved.

Considering the interaction effect of crop rotation by conservation practice, crop rotation where pepper was included (maize-wheat-pepper and maize-pepper-pepper rotations) plus conservation practice showed high clay percentage of $75.3 \%$ and $77 \%$, respectively (Table 2). The probable reason for such result may be construction of soil bund along the contour to reduce erosion and siltation of fine soil particles and impose to build up on-site because such farmlands have high clay percentage due to highintensity interventions. In parallel to the interaction effect of crop rotations by unconserved farmlands, maize-wheatpepper and maize-pepper-pepper rotations also showed $72.3 \%$ and $75.7 \%$ of clay content, respectively. Therefore, inclusion of pepper crop under crop rotations of a given farmland is advantageous to increase percentage of clay and associated clay-dependent soil properties.

\subsection{Soil Chemical Properties}

3.2.1. Soil Reaction $(p H)$. There was a significant $(p<0.05)$ effect of crop rotation, conservation practice, and their interaction on soil $\mathrm{pH}$ (Tables 2 and 3 ). According to the rating Foth et al. [31, 32], the $\mathrm{pH}$ value of all studied farmlands in the study area was classified as acidic (maize-wheat-pepper and maize-pepper-pepper) to moderately acidic. The soils in the study area was generally acidic (Table 4); this was expected since the inherent soils in the study area, the Nitisols and Alisols, are acidic in nature. Soil samples taken from maize-wheat-pepper rotation were the most acidic (4.88) followed by maize-pepper-pepper (4.98) with the greatest $\mathrm{pH}$ recorded under maize-wheat-faba bean rotation (5.44) (Table 3).

The two rotations that contain pepper had the most acidic $\mathrm{pH}$ value as compared to other rotations. The relatively low value in the $\mathrm{pH}$ of two rotations where pepper crop was included might be related to the excess use of 
TABLE 2: Interaction effects of crop rotations and conservation practice on soil physical and chemical properties.

\begin{tabular}{|c|c|c|c|c|c|c|c|c|c|c|c|c|}
\hline Treatments & Sand & $\begin{array}{l}\text { Silt } \\
(\%)\end{array}$ & Clay & $\begin{array}{c}\mathrm{pH} \\
\left(\mathrm{H}_{2} \mathrm{O}\right)\end{array}$ & $\begin{array}{c}\text { Ex. aci } \\
\left(\mathrm{cmol}_{\mathrm{C}} / \mathrm{kg}\right)\end{array}$ & Ex. Ca & $\begin{array}{l}\text { Ex. } \mathrm{Mg} \\
(\mathrm{cm}\end{array}$ & $\begin{array}{l}\text { Ex. K } \\
\text { (kg) }\end{array}$ & Ex. $\mathrm{Na}$ & $\begin{array}{c}\text { Av.P } \\
(\mathrm{ppm})\end{array}$ & TN & $\mathrm{OM}$ \\
\hline $\mathrm{MMM} * \mathrm{Un}$ & $20.3^{\mathrm{a}}$ & $19^{\mathrm{cd}}$ & $60.7^{\mathrm{h}}$ & $5.1^{\mathrm{a}}$ & $2.56^{\mathrm{f}}$ & $9.3^{g}$ & $5.4^{\mathrm{d}}$ & $0.3^{j}$ & $0.8^{\mathrm{e}}$ & $7.8^{\mathrm{e}}$ & $0.23^{\mathrm{h}}$ & $4.56^{\mathrm{e}}$ \\
\hline $\mathrm{MMM} * \mathrm{Co}$ & $19^{\mathrm{a}}$ & $20.3^{\mathrm{a}}$ & $60.7^{\mathrm{h}}$ & $5.6^{\mathrm{d}}$ & $1.81^{\mathrm{h}}$ & $11.3^{\mathrm{e}}$ & $6.6^{\mathrm{b}}$ & $0.4^{\mathrm{i}}$ & $0.2^{\mathrm{f}}$ & $12.6^{\mathrm{a}}$ & $0.24^{\text {fgh }}$ & $4.6^{\mathrm{de}}$ \\
\hline $\mathrm{MWM} * \mathrm{Un}$ & $16^{\mathrm{b}}$ & $14.3^{\mathrm{f}}$ & $69.7^{\mathrm{de}}$ & $4.7^{\mathrm{f}}$ & $2.75^{\mathrm{c}}$ & $9.6^{\mathrm{fg}}$ & $6^{c}$ & $0.4^{\mathrm{i}}$ & $0.8^{\mathrm{d}}$ & $7.4^{\mathrm{ef}}$ & $0.22^{\mathrm{i}}$ & $4.53^{\mathrm{e}}$ \\
\hline $\mathrm{MWM} * \mathrm{Co}$ & $12^{\mathrm{c}}$ & $19.3^{\mathrm{cd}}$ & $68^{\mathrm{ef}}$ & $5.6^{\mathrm{a}}$ & $1.71^{\mathrm{i}}$ & $12.8^{\mathrm{d}}$ & $7^{\mathrm{ab}}$ & $1.2^{\mathrm{g}}$ & $0.2^{\mathrm{f}}$ & $9.3^{c}$ & $0.24^{\mathrm{ef}}$ & $4.9^{c}$ \\
\hline $\mathrm{MWW} * \mathrm{Un}$ & $15.7^{\mathrm{b}}$ & $22^{\mathrm{b}}$ & $62.3^{\mathrm{gh}}$ & $4.9^{\mathrm{e}}$ & $4.89^{\mathrm{a}}$ & $10.2^{\mathrm{f}}$ & $4.9^{\mathrm{d}}$ & $2.01^{\mathrm{a}}$ & $0.8^{\mathrm{d}}$ & $5.6^{\mathrm{h}}$ & $0.2^{\mathrm{j}}$ & $4.53^{\mathrm{e}}$ \\
\hline $\mathrm{MWP} * \mathrm{Co}$ & $12.3^{c}$ & $20.3^{\mathrm{cb}}$ & $67.3^{\mathrm{ef}}$ & $5.3^{\mathrm{c}}$ & $3.34^{\mathrm{b}}$ & $12.94^{\mathrm{d}}$ & $6.8^{\mathrm{b}}$ & $2.04^{\mathrm{a}}$ & $0.2^{\mathrm{f}}$ & $6.6^{\mathrm{g}}$ & $0.22^{\mathrm{i}}$ & $4.64^{\mathrm{d}}$ \\
\hline $\mathrm{MWW} * \mathrm{Un}$ & $8.7^{\mathrm{e}}$ & $19^{\mathrm{cd}}$ & $72.3^{\mathrm{abc}}$ & $4.8^{\mathrm{ef}}$ & $2.3^{\text {ef }}$ & $10.17^{\mathrm{f}}$ & $5.1^{\mathrm{d}}$ & $1.5^{\mathrm{e}}$ & $1.04^{\mathrm{c}}$ & $5.3^{\mathrm{h}}$ & $0.24^{\text {gh }}$ & $5^{\mathrm{bc}}$ \\
\hline $\mathrm{MWP} * \mathrm{Co}$ & $7.3^{\mathrm{ef}}$ & $17.3^{\text {ed }}$ & $75.3^{\mathrm{abc}}$ & $5.03^{\mathrm{d}}$ & $1.81^{\mathrm{h}}$ & $13.02^{\mathrm{d}}$ & $7^{\mathrm{ab}}$ & $1.8^{\mathrm{b}}$ & $0.2^{\mathrm{f}}$ & $10.3^{\mathrm{b}}$ & $0.26^{\mathrm{cd}}$ & $5.1^{\mathrm{b}}$ \\
\hline $\mathrm{MPP} * \mathrm{Un}$ & $6^{\mathrm{f}}$ & $18.3^{\mathrm{d}}$ & $75.7^{\mathrm{ab}}$ & $4.83^{\mathrm{e}}$ & $2.72^{\mathrm{C}}$ & $13.3^{\mathrm{cd}}$ & $5.24^{\mathrm{d}}$ & $1.44^{\mathrm{f}}$ & $1.18^{\mathrm{a}}$ & $5.6^{\mathrm{h}}$ & $0.24^{\mathrm{fg}}$ & $5.1^{\mathrm{bc}}$ \\
\hline $\mathrm{MPP} * \mathrm{Co}$ & $7.3^{\mathrm{ef}}$ & $15.7^{\mathrm{ef}}$ & $77^{\mathrm{a}}$ & $5.1^{\mathrm{d}}$ & $2.36^{\mathrm{e}}$ & $14.5^{\mathrm{b}}$ & $6.82^{\mathrm{b}}$ & $1.71^{\mathrm{c}}$ & $0.2^{\mathrm{f}}$ & $8.97^{\mathrm{cd}}$ & $0.25^{\mathrm{cd}}$ & $5.2^{\mathrm{a}}$ \\
\hline $\mathrm{MWFb} * \mathrm{Un}$ & $9.3^{\mathrm{de}}$ & $25^{\mathrm{a}}$ & $65.7^{\mathrm{fg}}$ & $5.31^{\mathrm{c}}$ & $2.51^{\mathrm{d}}$ & $13.8^{\mathrm{c}}$ & $5.3^{\mathrm{d}}$ & $1.04^{\mathrm{h}}$ & $1.1^{\mathrm{cb}}$ & $7.1^{\mathrm{fg}}$ & $0.25^{\mathrm{cd}}$ & $4.9^{c}$ \\
\hline $\mathrm{MWFb} * \mathrm{Co}$ & $12.7^{\mathrm{c}}$ & $24.7^{\mathrm{a}}$ & $65.7^{\mathrm{fg}}$ & $5.6^{\mathrm{ab}}$ & $2.03^{\mathrm{g}}$ & $14.7^{\mathrm{b}}$ & $6.8^{\mathrm{b}}$ & $1.6^{\mathrm{d}}$ & $0.22^{\mathrm{f}}$ & $8.5^{\mathrm{d}}$ & $0.27^{\mathrm{b}}$ & $5.1^{\mathrm{bc}}$ \\
\hline $\mathrm{MFbP} * \mathrm{Un}$ & $11.3^{\mathrm{cd}}$ & $18^{\mathrm{d}}$ & $72^{\mathrm{cd}}$ & $5.32^{c}$ & $2.3^{\mathrm{ef}}$ & $15.12^{\mathrm{ab}}$ & $5.1^{\mathrm{d}}$ & $1.03^{\mathrm{h}}$ & $1.11^{\mathrm{b}}$ & $7.02^{\mathrm{fg}}$ & $0.23^{\mathrm{bc}}$ & $5.1^{\mathrm{bc}}$ \\
\hline $\mathrm{MFbP} * \mathrm{Co}$ & $12.3^{c}$ & $18.3^{\mathrm{cd}}$ & $70^{\mathrm{de}}$ & $5.5^{\mathrm{b}}$ & $2.02^{\mathrm{g}}$ & $15.44^{\mathrm{a}}$ & $7.3^{\mathrm{a}}$ & $1.52^{\mathrm{de}}$ & $0.2^{\mathrm{f}}$ & $8.9^{\mathrm{cd}}$ & $0.28^{\mathrm{a}}$ & $4.96^{\mathrm{c}}$ \\
\hline$p$-value & $* * *$ & $* * *$ & $*$ & $* * *$ & $* * *$ & $* * *$ & $* *$ & $* * *$ & $* * *$ & $* * *$ & * & $* *$ \\
\hline CV (\%) & 11.06 & 5.81 & 2.78 & 1.52 & 1.96 & 3.16 & 3.91 & 2.24 & 4.49 & 4.02 & 1.71 & 3.26 \\
\hline
\end{tabular}

Means followed by the same letter(s) within the same treatment group are statistically the same and showed no significant difference by DMRT $(p<0.05)$. ${ }^{*},{ }^{* *}$, and ${ }^{* * *}$ mean significant differences at $0.05,0.01$, and 0.001 probability levels, respectively, and NS means nonsignificant differences.

TABLE 3: Mean values of soil $\mathrm{pH}$, available phosphorus, total nitrogen, organic carbon, organic matter, and $\mathrm{C}: \mathrm{N}$ ratio in response to crop rotation treatments and conservation practice.

\begin{tabular}{lcccccc}
\hline \multirow{4}{*}{ Treatment } & $\begin{array}{c}\mathrm{pH} \\
(1: 1.5\end{array}$ & $\begin{array}{c}\text { Av.P } \\
(\mathrm{ppm})\end{array}$ & $\mathrm{TN}$ & $\mathrm{OC}$ & $\mathrm{OM}$ & $\mathrm{C}: \mathrm{N}$ \\
& $\left.\mathrm{H}_{2} \mathrm{O}\right)$ & & & \\
& & & & \\
\hline Crop rotation & & & & & & \\
(CR) & & & & & & \\
MMM & $5.34^{\mathrm{a}}$ & $10.21^{\mathrm{a}}$ & $0.23^{\mathrm{d}}$ & $2.63^{\mathrm{d}}$ & $4.53^{\mathrm{d}}$ & $11.41^{\mathrm{d}}$ \\
MWM & $5.15^{\mathrm{b}}$ & $8.37^{\mathrm{b}}$ & $0.23^{\mathrm{d}}$ & $2.7^{\mathrm{c}}$ & $4.66^{\mathrm{c}}$ & $11.74^{\mathrm{c}}$ \\
MWW & $5.08^{\mathrm{b}}$ & $6.09^{\mathrm{e}}$ & $0.21^{\mathrm{e}}$ & $2.66^{\mathrm{cd}}$ & $4.58^{\mathrm{cd}}$ & $12.66^{\mathrm{a}}$ \\
MWP & $4.88^{\mathrm{d}}$ & $7.76^{\mathrm{c}}$ & $0.24^{\mathrm{c}}$ & $2.93^{\mathrm{a}}$ & $5.05^{\mathrm{a}}$ & $12.2^{\mathrm{b}}$ \\
MPP & $4.98^{\mathrm{c}}$ & $7.23^{\mathrm{d}}$ & $0.25^{\mathrm{c}}$ & $2.97^{\mathrm{a}}$ & $5.12^{\mathrm{a}}$ & $11.9^{\mathrm{b}}$ \\
MWFb & $5.44^{\mathrm{a}}$ & $7.79^{\mathrm{c}}$ & $0.26^{\mathrm{b}}$ & $2.85^{\mathrm{b}}$ & $4.91^{\mathrm{b}}$ & $10.96^{\mathrm{de}}$ \\
MFbP & $5.4^{\mathrm{a}}$ & $7.95^{\mathrm{c}}$ & $0.28^{\mathrm{a}}$ & $2.91^{\mathrm{a}}$ & $5.02^{\mathrm{ab}}$ & $10.4^{\mathrm{e}}$ \\
\hline Con. practice & & & & & & \\
(CP) & & & & & & \\
Conserved & $5.34^{\mathrm{a}}$ & $9.31^{\mathrm{a}}$ & $0.25^{\mathrm{a}}$ & $2.84^{\mathrm{a}}$ & $4.9^{\mathrm{a}}$ & $11.36^{\mathrm{b}}$ \\
Unconserved & $4.97^{\mathrm{b}}$ & $6.53^{\mathrm{b}}$ & $0.23^{\mathrm{b}}$ & $2.77^{\mathrm{ab}}$ & $4.77^{\mathrm{b}}$ & $12.04^{\mathrm{a}}$ \\
CR & $* * *$ & $* * *$ & $* * *$ & $* * *$ & $* * *$ & $* * *$ \\
CP & $* * *$ & $* * *$ & $* * *$ & $* *$ & $* * *$ & $* * *$ \\
CV (\%) & 1.52 & 4.02 & 1.71 & 1.91 & 3.26 & 2.39 \\
\hline
\end{tabular}

Means followed by the same letter(s) within the same treatment group are statistically the same and showed no significant difference by DMRT $(p<0.05) .{ }^{*},{ }^{* *}$, and ${ }^{* * *}$ mean significant differences at $0.05,0.01$, and 0.001 probability levels, respectively, and NS means nonsignificant differences.

applied nitrogen fertilizers more frequently in pepper cultivated lands than in the other rotations, beyond uptake capacity (i.e., three times per cropping season). Continuous use of ammonium-based fertilizers such as diammonium phosphate $\left(\left(\mathrm{NH}_{4}\right)_{2} \mathrm{HPO}_{4}\right)$ and urea $\left(\left(\mathrm{NH}_{2}\right)_{2} \mathrm{CO}\right)$. Continued use of nitrogen-containing fertilizers seems to have contributed to increased soil acidity as well as accentuating the uptake and deficiency of other nutrients such as potassium and available $\mathrm{P}$ that is not supplied in the fertilizer application. Acidic nature of Nitisol was also reported by Yihenew [33].
TABLE 4: Mean values of exchangeable acidity, cation exchange capacity, and exchangeable bases in response to crop rotation treatments and conservation practice.

\begin{tabular}{lcccccc}
\hline Treatment & $\begin{array}{c}\text { Ex. } \\
\text { acidity }\end{array}$ & CEC & $\begin{array}{c}\text { Ex. } \\
\text { Ca } \\
\mathrm{cmol}_{\mathrm{c}} / \mathrm{kg}\end{array}$ & $\begin{array}{c}\text { Ex. } \\
\mathrm{Mg}\end{array}$ & $\begin{array}{c}\text { Ex. } \\
\text { K }\end{array}$ & $\begin{array}{c}\text { Ex. } \\
\mathrm{Na}\end{array}$ \\
\hline $\begin{array}{l}\text { Crop rotation } \\
\text { (CR) }\end{array}$ & & & & & & \\
MMM & $2.03^{\mathrm{e}}$ & $45.17^{\mathrm{f}}$ & $10.29^{\mathrm{d}}$ & $6.00^{\mathrm{b}}$ & $0.36^{\mathrm{f}}$ & $0.45^{\mathrm{d}}$ \\
MWM & $2.23^{\mathrm{c}}$ & $46.73^{\mathrm{e}}$ & $11.57^{\mathrm{c}}$ & $6.48^{\mathrm{a}}$ & $0.8^{\mathrm{e}}$ & $0.48^{\mathrm{cd}}$ \\
MWW & $4.12^{\mathrm{a}}$ & $48.05^{\mathrm{bc}}$ & $12.17^{\mathrm{c}}$ & $5.88^{\mathrm{b}}$ & $2.03^{\mathrm{a}}$ & $0.49^{\mathrm{c}}$ \\
MWP & $2.04^{\mathrm{e}}$ & $47.5^{\mathrm{cd}}$ & $11.59^{\mathrm{c}}$ & $6.03^{\mathrm{b}}$ & $1.64^{\mathrm{b}}$ & $0.62^{\mathrm{b}}$ \\
MPP & $2.53^{\mathrm{b}}$ & $48.03^{\mathrm{bc}}$ & $13.87^{\mathrm{b}}$ & $6.03^{\mathrm{b}}$ & $1.58^{\mathrm{c}}$ & $0.68^{\mathrm{a}}$ \\
MWFb & $2.27^{\mathrm{c}}$ & $48.57^{\mathrm{b}}$ & $14.22^{\mathrm{b}}$ & $6.02^{\mathrm{b}}$ & $1.29^{\mathrm{d}}$ & $0.65^{\mathrm{b}}$ \\
MFbp & $2.16^{\mathrm{d}}$ & $49.47^{\mathrm{a}}$ & $15.28^{\mathrm{a}}$ & $6.17^{\mathrm{b}}$ & $1.27^{\mathrm{d}}$ & $0.65^{\mathrm{b}}$ \\
\hline Con. Practice & & & & & & \\
(CP) & & & & & & \\
Conserved & $2.15^{\mathrm{b}}$ & $48.3^{\mathrm{a}}$ & $13.53^{\mathrm{a}}$ & $6.89^{\mathrm{a}}$ & $1.46^{\mathrm{a}}$ & $0.2^{\mathrm{b}}$ \\
Unconserved & $2.82^{\mathrm{a}}$ & $46.87^{\mathrm{b}}$ & $11.61^{\mathrm{b}}$ & $5.28^{\mathrm{b}}$ & $1.11^{\mathrm{b}}$ & $0.56^{\mathrm{a}}$ \\
CR & $* * *$ & $* * *$ & $* * *$ & $* *$ & $* * *$ & $* * *$ \\
CP & $* * *$ & $* * *$ & $* * *$ & $* * *$ & $* * *$ & $* * *$ \\
CV(\%) & 1.96 & 0.99 & 3.16 & 3.91 & 2.24 & 4.49 \\
\hline
\end{tabular}

Means followed by the same letter(s) within the same treatment group are statistically the same and showed no significant difference by DMRT $(p<0.05) .^{*},{ }^{* *}$, and ${ }^{* * *}$ mean significant differences at $0.05,0.01$, and 0.001 probability levels, respectively, and NS means nonsignificant differences.

The other reason might be decaying of active organic matter and numerous release of $\mathrm{H}^{+}$which is responsible for acidity. The carbon dioxide $\left(\mathrm{CO}_{2}\right)$ produced by decaying organic matter reacts with water in the soil to form a weak acid called carbonic acid. Several organic acids are also produced by decaying organic matter, but they are also weak acids. Hulugalle and Weaver [34] also showed that a decrease in $\mathrm{pH}$ is among the short-term changes of soil properties that result from the production of organic acids during the decomposition of crop residues. The humid climatic conditions also might have resulted in increased 
microbial oxidation to produced organic acids, which provide $\mathrm{H}^{+}$to the soil that can also contribute towards low soil $\mathrm{pH}$ [35].

Reduced acidification under rotations with faba bean might be related to very low amount of nitrogen fertilizer has been applied in a given farmland to grow faba bean. The result was similar with the previous study conducted by Nuruzzaman et al. [36], who indicated that soil acidity reduces due to more frequent faba bean, and therefore, less nitrogen fertilization has been used. However, the result was in contrast with the findings of Helyar and Porter [37], who state that legumes can increase soil acidity through increase in soil organic carbon, $\mathrm{N}$-fixation, and subsequent oxidation of such organic $\mathrm{N}$ followed by leaching of nitrate.

From all crop rotations, an interesting third rank result of high soil $\mathrm{pH}$ value (5.34) was recorded under continuous maize (i.e., the control). The reason in relatively high soil $\mathrm{pH}$ under three-year continuous maize might be "madager"/ shilshalo/ plowing practice (plowing along with standing crop some weeks after emergence), purposively for second time weeding. Consequently, the furrows create favorable conditions to maize roots, enhance ability to take the applied fertilizer before acidity is formed from nitrification process, and also reduce leaching of nitrate.

Considering the main effect of conservation practice, farmlands conserved with soil bund indicated that higher soil $\mathrm{pH}$ value (5.34) than the unconserved one (4.97) (Table 3). There was an increase in mean soil $\mathrm{pH}$ across the conserved farmlands from nonconserved with soil bund. The relative decrease in soil $\mathrm{pH}$ of unconserved farmland can be attributed to the extent of soil erosion or the leaching of basic cations. Such a result was in line with the finding of Birhane et al. [38].

Considering the interaction effect of crop rotation by conservation practice, three year continuous maize and maize-wheat-faba bean plus soil bund showed high $\mathrm{pH}$ value (5.6), while low $\mathrm{pH}$ values 4.8 and 4.83 were recorded under maize-wheat-pepper and maize-pepper-pepper rotations, respectively, plus unconserved (Table 2). This indicates more cation-containing residue was retained through construction of soil bund in the area.

3.2.2. Available Phosphorus. There was a significant $(p<0.05)$ effect of crop rotation, conservation practice, and their interaction on soil available $P$ (Tables 2 and 3 ). Phosphorus concentrations varied across crop rotations with mean $6.09,7.23,7.78,7.79,7.95,8.37$, and $10.21 \mathrm{ppm}$ under maize-wheat-wheat, maize-pepper-pepper, maizewheat-pepper, maize-wheat-faba bean, maize-faba beanpepper, maize-wheat-maize, and continuous maize, respectively (Table 3). According to Olsen et al. [39], the mean values of available P (Olsen P under heavy clay soil) under each crop rotation, conservation practice, and their interaction were recorded at a low rate. According to Brady [40], the optimum $\mathrm{P}$ availability in the soil is when soil reaction $(\mathrm{pH})$ range is between 6 and 7 . The $\mathrm{pH}$ in the current study ranged from 4.88 to $5.44 \mathrm{ppm}$, indicating there is $\mathrm{P}$ fixation that leads to low availability. A probable reason in relatively high level of available $\mathrm{P}$ under continuous maize (10.21 ppm) was due to the slightly acidic condition of the soil taken from such farmlands.

Amount of available $\mathrm{P}$ was also good under crop rotations on which faba bean was included. This might be because large organic acids released from roots of faba bean can help mobilize $P$ from soil $P$ pools, which makes available to plants that do not possess this adaptation. The main reason for such condition will be $\mathrm{Al}^{3+}$ ions form more stable complexes with organic acids and $\mathrm{P}$ becomes free in the soil. The result was in line with that of the study of Nuruzzaman et al. [41] who revealed that certain legume crops, including faba beans, exude large amounts of organic acids into the rhizosphere. Under such conditions, these exudates can help to mobilize P from soil P pools and increase its availability.

Relatively low amount of available $\mathrm{P}(6.09 \mathrm{ppm})$ was recorded under maize-wheat-wheat rotation (Table 3 ). In line with the study conducted by Osman [42], the reason for such low available $\mathrm{P}$ might be resulted from high exchangeable acidity that $\mathrm{P}$ is combined with $\mathrm{Al}, \mathrm{Fe}$, and $\mathrm{Mn}$ (as their presence is expected at the $\mathrm{pH}$ values of the soils of the study area) and becomes fixed. High phosphorous sorption capacity of Nitisol under all land use types was also reported by WRB [43].

Considering conservation practice, a relatively high mean value of available $\mathrm{P}$ was recorded under farmlands treated with soil bund $(9.31 \mathrm{ppm})$ than unconserved (6.53 ppm) in the study area (Table 3 ). This might be because construction of soil bund reduces removal of some of the applied P fertilizer from the farmland. Gete [6] also mentioned that the presence of higher storms in June, July, and August associated with poor land management factor that causes severe soil erosion from unconserved farm fields in Dembecha District. This condition could also lead to the removal of available $\mathrm{P}$ including other nutrients from the topsoil in the study area.

3.2.3. Soil Organic Matter. Soil organic matter was significantly $(p<0.05)$ affected by crop rotation, conservation practice, and their interaction (Tables 2 and 3). According to Charman and Roper [44], the analysis of variance indicated that high content of soil OM was recorded in all crop rotation treatments with cereals and legumes. Maize-wheatpepper and maize-pepper-pepper rotations record highest OM contents (5.05 and 5.12\%), respectively. The reason might be slow decay of roots and other biomass of pepper crop through various forms of active soil OM that further tend to stabilize soil aggregates and supply a slow release of nutrients.

The result was in contrast with the study conducted by Yihenew [33] who indicated that most cultivated soils of Ethiopia, in general, are poor in their OM content due to low amount of organic materials applied to the soil and complete removal of the biomass from the field. However, the result was in line with that of the study accompanied by Shimeles et al. [45] and Wakene and Heluf [46] who reported that high OM was observed under Nitisols. The surface soils of Nitisol may also contain high percent of organic matter [43]. 
The highest values of OM content could be because of high amount of rainfall that reduces the rate of organic materials decomposition in the study sites.

Considering conservation practice, the soil OM content under unconserved farmlands $(4.9 \%)$ was lower than conserved farmlands $(4.77 \%)$. The relatively high percentage of soil $\mathrm{OM}$ occurred under unconserved farmlands could be attributed to the presence of significantly higher organic residue deposition from arriving sediment loaded runoff as a result of conservation practice (Table 3). The result agrees with the finding of Abay et al. [27], who reported that unconserved lands had significantly lower soil $\mathrm{OM}$ as compared to the conserved lands treated with different conservation measures. Kebede et al. [47] also stated that soil and water conservation with soil bund reduces surface runoff and soil loss, retains water that enhances crop growth, and contributes to soil OM input.

Considering the interaction effect of crop rotation by conservation practice, soil $\mathrm{OM}$ under all crop rotation treatments plus conservation practice was better than adjacent farmlands without any conservation practice (Table 2). This finding infers that construction of soil bunds enables the incorporation of $\mathrm{OM}$ from the upcoming residue loaded runoff into the soil.

Soil organic carbon (soil OC) was significantly $(p<0.05)$ affected by crop rotation, conservation practice, and their interaction (Tables 2 and 3). According to Fairhurst [48], the critical limit for soil OC is $1.5 \%$; therefore, the soil OC in all treatments of this study was above the optimum critical level. The mean value was significantly high under maizepepper-pepper (2.97\%) followed by maize-wheat-pepper (2.93) and low under continuous maize (2.63\%) (Table 3). Continuous and intensive cultivation of maize leading to high crop biomass removal could be the reason for relatively low OC content. McDaniel et al. [49] also examined the influence of rotation types and management practices on carbon and nitrogen dynamics. Adding diverse crops and legumes in rotation compared to a monoculture increased soil carbon by $3.6 \%$ and total nitrogen by $5.3 \%$.

Furthermore, such a result was in line with the study conducted by Huang et al. [50], since OC and total $\mathrm{N}$ are stoichiometrically linked in soil OM, a greater content of soil $\mathrm{OM}$ invariably led to an increase in soil $\mathrm{OC}$ and total $\mathrm{N}$ under rotations where pepper and faba bean were included over time.

3.2.4. Total Nitrogen. Percentage of soil total $\mathrm{N}$ was significantly $(p<0.05)$ affected by crop rotation, conservation practice, and their interaction (Tables 2 and 3). The mean total $N$ values, $0.21-0.28 \%$ for all treatments, were rated as medium based on the ratings of Landon (1991). Even if all the treatments showed medium percentage of total N, there was variation of the values among some treatments ranges from $0.21-0.28 \%$ under maize-wheat-wheat and maize-faba bean-pepper rotation, respectively. Rotations on which faba bean was incorporated (maize-wheat-faba bean and maizefaba bean-pepper) showed high percentage of total $\mathrm{N} 0.26$ and $0.28 \%$, respectively, compared to other crop rotations
(Table 3). This result was in contrary with that of Jagadamma et al. [51] who reported greater total $\mathrm{N}$ under three-year continuous maize than a corn soya bean rotation in the surface $20 \mathrm{~cm}$. Okpara and Lgwe [52] indicated that legumecereal rotations gave higher soil $\mathrm{N}$ than continuous maize whether there was addition of residues or not.

The " $\mathrm{N}$ credit" under rotations where faba bean was included is likely due to biological nitrogen fixation through its roots and root exudates, increasing the pool of easily mineralized organic $\mathrm{N}$ as revealed by Murrell [53].

However, maize-wheat-wheat rotation showed low percentage of total $\mathrm{N}(0.21)$ compared to other rotations. This might be due to the nature of straw reach in organic carbon with low input of nitrogen containing fertilizers. Organic matter rich in carbon provides a large source of energy to soil micro-organisms. Consequently, it brings population expansion of microorganism and higher consumption of mineralized $\mathrm{N}$.

Considering conservation practice, the statistical analysis revealed that mean values of total $\mathrm{N}$ percentage under conserved and unconserved farmlands were 0.25 and $0.23 \%$, respectively (Table 3 ). The result was in line with the study conducted by Abay et al. [27], and Mulugeta and Stahr [26] also identified higher total $\mathrm{N}$ content in farm plots with physical conservation measures as compared to the unconserved lands.

Considering the interaction effect of crop rotation by conservation practice, maize-wheat-pepper, maize-wheatfaba bean, and maize-faba bean-pepper rotations plus conservation practice showed relatively high percentage of total $\mathrm{N}$ with mean values $0.26,0.27$, and $0.28 \%$, respectively. However, relatively low percentage of total $\mathrm{N}$ was recorded under maize-wheat-wheat and maize-wheat-maize rotations without conservation practice with mean value of 0.2 and $0.23 \%$, respectively (Table 2 ). Therefore, physical soil and water conservation measure implemented over farmlands with $\mathrm{N}$ fixing crop have indicated higher total $\mathrm{N}$ compared with other treatments.

3.2.5. Carbon to Nitrogen Ratio $(C: N)$. Crop rotation and conservation practice significantly $(p<0.05)$ affect C:N ratio. However, their interaction does not affect $\mathrm{C}: \mathrm{N}$ ratio. Even if C:N ratio varied slightly across rotations, it ranges from 10.4 to 12.66 under maize-faba bean-pepper in maizewheat-wheat, respectively (Table 3 ). The relatively high amount of nitrogen under rotations where faba bean was included might be a cause for low C:N ratio. However, C:N ratio was relatively high under rotations where wheat was included, due to high contents of carbon on wheat straw. The result was supported by McDaniel et al. [54] who reported that residue from rotations where wheat was included had a wider $\mathrm{C}: \mathrm{N}$ and had more lignin than the other rotations. Conversion of carbon in crop residue and other organic materials applied to the soil into decomposed form through microorganisms requires nutrients mainly nitrogen. Consequently, the contents of total $\mathrm{N}$ become low and cause high in $\mathrm{C}: \mathrm{N}$ ratio of the soil. Although rate of decomposition was not measured in this study, the relatively high $\mathrm{C}: \mathrm{N}$ ratio was 
an indication of somewhat depressed N-mineralization under maize-wheat-wheat rotation.

Considering conservation practice, there was a slight decrease in $\mathrm{C}: \mathrm{N}$ ratio of farmlands conserved with soil bund (12.04) than unconserved (11.36) (Table 3). This might be because of the existing conservation practice creating satisfactory conditions in terms of moisture content and necessary nutrients to microorganisms in order to easily decompose the carbon containing components.

3.2.6. Exchangeable Acidity. Soil exchangeable acidity was significantly $(p<0.05)$ affected by crop rotation, conservation practice, and their interaction (Tables 2 and 4 ). The mean values ranged from low $\left(2.02 \mathrm{cmol}_{\mathrm{c}} / \mathrm{kg}\right)$ under continuous maize to high $\left(4.12 \mathrm{cmol}_{c} / \mathrm{kg}\right)$ under maize-wheatwheat rotation (Table 4). The high value of exchangeable acidity under maize-wheat-wheat rotation might be due to application of urea fertilizer at the time of sowing, while it may not be properly used early by the seed to start its growth formation.

Considering conservation practice, farmlands conserved with soil bund showed relatively low contents of exchangeable acidity $\left(2.15 \mathrm{cmol}_{\mathcal{C}} / \mathrm{kg}\right)$ than unconserved ones $\left(2.82 \mathrm{cmol}_{\mathrm{c}} / \mathrm{kg}\right.$ ) (Table 4). This might because the concentration of basic cations in the soil was high due to construction of soil bund otherwise going to be removed through erosion from the area.

Considering the interaction effect of crop rotation by conservation practice, the lowest exchangeable acidity mean value $\left(1.71 \mathrm{cmol}_{\mathrm{c}} / \mathrm{kg}\right)$ was recorded under maize-wheatmaize rotation of the treated cultivation land, whereas the highest $\left(4.89 \mathrm{cmol}_{\mathrm{c}} / \mathrm{kg}\right)$ was observed maize-wheat-wheat rotation of the farmland plus conservation practice (Table 2). Generally, the study revealed values of exchangeable acidity were lower under conserved farmlands than unconserved across all crop rotations.

3.2.7. Cation Exchange Capacity (CEC). CEC was significantly $(p<0.05)$ affected by crop rotation and conservation practice. However, it was not significantly $(p>0.05)$ affected by their interaction. The value of CEC among various crop rotations varied from 45.17 to $49.47 \mathrm{cmol}_{\mathrm{c}} / \mathrm{kg}$. The mean value was high under maize-faba bean-pepper $\left(49.47 \mathrm{cmol}_{c} /\right.$ $\mathrm{kg})$ followed by maize-wheat-faba bean $\left(48.57 \mathrm{cmol}_{\mathrm{c}} / \mathrm{kg}\right)$ and low under maize-wheat-wheat $\left(44.05 \mathrm{cmol}_{\mathrm{c}} / \mathrm{kg}\right.$ ) (Table 4). Following Hazelton and Murphy [55], the rating of CEC greater than $40 \mathrm{cmol}_{\mathrm{c}} / \mathrm{kg}$ was considered as very high, 25 to $40 \mathrm{cmol}_{\mathrm{c}} / \mathrm{kg}$ as high, 12 to $25 \mathrm{cmol}_{\mathrm{c}} / \mathrm{kg}$ as medium, 6 to $12 \mathrm{cmol}_{\mathrm{c}} / \mathrm{kg}$ as low, and less than $6 \mathrm{cmol}_{\mathcal{c}} / \mathrm{kg}$ as very low; soils of the study area could be regarded as very high CEC.

The high clay fraction along with soil OM may attribute to high rate of soil CEC in the study site. The result was in line with the study conducted by Fasil and Charles [56] who reported that the amount of clay and amount of organic matter present in the soil are responsible factors for increase in soil CEC. Thus, soils containing high clay and organic matter contents have high cation exchange capacity.
Considering conservation practice, mean value of CEC was relatively higher under conserved farmlands $\left(48.3 \mathrm{cmol}_{\mathrm{c}} / \mathrm{kg}\right.$ ) than unconserved $\left(46.87 \mathrm{cmol}_{\mathrm{c}} / \mathrm{kg}\right) \quad(\mathrm{Ta}-$ ble 4). The reason might be due to presence of slight increase in amount of clay mineral and OM under conserved farmlands as a result of some deposition. This result was in line with the study conducted by Behailu et al. [57] who reported that cultivated lands conserved with soil bund showed higher value of CEC than unconserved under three slope positions.

3.2.8. Exchangeable Bases. The analysis of variance revealed there was significant $(p<0.05)$ effects of crop rotation, conservation practice, and their interaction in all exchangeable bases $\left(\mathrm{Ca}^{2+}, \mathrm{Mg}^{2+}, \mathrm{K}^{+}\right.$, and $\left.\mathrm{Na}^{+}\right)$(Tables 2 and 4$)$. According to Metson [58], the values of exchangeable bases were found at high rate $\left(\mathrm{Ca}^{2+}\right.$ and $\left.\mathrm{Mg}^{2+}\right)$ and moderate to high $\left(\mathrm{K}^{+}\right.$and $\left.\mathrm{Na}^{+}\right)$(Table 2). The general trend in all the cropping sequences indicated that the content of all exchangeable bases was relatively higher in crop rotations treatments than monocropping. Considering the interaction effect of crop rotations by conservation practice, all exchangeable bases except exchangeable $\mathrm{Na}^{+}$showed a relative increase under all crop rotations plus conservation practice (Table 2).

The content of exchangeable $\mathrm{Ca}^{2+}$ was significantly $(p<0.05)$ affected by crop rotations, conservation practice and their interaction (Tables 2 and 4 ). The mean values varied from 10.29 to $15.28 \mathrm{cmol}_{\mathcal{C}} / \mathrm{kg}$. Relatively exchangeable $\mathrm{Ca}^{2+}$ was high under maize-faba bean-pepper $\left(15.28 \mathrm{cmol}_{\mathcal{c}} /\right.$ $\mathrm{kg})$ followed by maize-wheat-faba bean $\left(14.22 \mathrm{cmol}_{\mathcal{c}} / \mathrm{kg}\right)$ and low under continuous maize $\left(10.29 \mathrm{cmol}_{\mathrm{c}} / \mathrm{kg}\right)$ (Table 4). The other three crop rotations were found with almost similar content of exchangeable $\mathrm{Ca}^{2+}$.

The relatively high value of exchangeable $\mathrm{Ca}^{2+}$ under maize-wheat-faba bean might be due to more stable complex formation of $\mathrm{Al}^{3+}$ ions with organic acids released from faba bean. Consequently, this process may cause a decrease in exchangeable acidity and thus increase exchangeable calcium in this soil layer. Low levels of exchangeable $\mathrm{Ca}^{2+}$ in the study area might be due to absence of any acidity reclamation activity until now, while continuous addition of acidifying chemical fertilizers has been continued.

Considering conservation practice, the value of exchangeable $\mathrm{Ca}^{2+}$ was relatively higher under conserved farmlands $\left(13.53 \mathrm{cmol}_{\mathrm{c}} / \mathrm{kg}\right)$ than unconserved $\left(11.61 \mathrm{cmol}_{\mathrm{c}} /\right.$ $\mathrm{kg}$ ) (Table 4). This is because that cultivated lands with physical soil and water conservation practice might have reduced soil erosion and leaching of exchangeable cations. The result was in line with that of the study conducted by Behailu et al. [57] who revealed that cultivated lands treated with soil bund showed higher value of exchangeable $\mathrm{Ca}^{2+}$ than unconserved one under higher, middle, and lower slope classes.

The exchangeable $\mathrm{Mg}^{2+}$ content of the soils was significantly $(p<0.05)$ affected by crop rotation, conservation practice, and their interaction and varied from 6 to $6.48 \mathrm{cmol}_{\mathcal{C}} / \mathrm{kg}$ with no significant variation among rotations 
(Tables 2 and 4). According to Metson [58], exchangeable $\mathrm{Mg}^{2+}$ was recorded at high rate. The relatively high and low values of exchangeable $\mathrm{Mg}^{2+}\left(6.48 \mathrm{cmol}_{\mathrm{c}} / \mathrm{kg}\right)$ and $\left(6 \mathrm{cmol}_{\mathrm{C}} /\right.$ $\mathrm{kg}$ ) were recorded under continuous maize and maizewheat-maize rotations, respectively (Table 4).

Conserved farmlands showed relatively higher amount of exchangeable $\mathrm{Mg}^{2+}\left(6.29 \mathrm{~mol}_{\mathrm{c}} / \mathrm{kg}\right)$ than unconserved $\left(5.28 \mathrm{cmol}_{\mathrm{c}} / \mathrm{kg}\right)$. Considering interaction effect of crop rotations by conservation practice, similar to effect of crop rotation alone, highest mean value of exchangeable $\mathrm{Ca}^{2+}$ $\left(15.44 \mathrm{cmol}_{\mathrm{c}} / \mathrm{kg}\right)$ and $\mathrm{Mg}^{2+}\left(7.3 \mathrm{cmol}_{\mathrm{c}} / \mathrm{kg}\right)$ were observed under maize-faba bean-pepper rotation plus conservation practice (Table 2).

Exchangeable $\mathrm{K}^{+}$concentrations were significantly $(p<0.05)$ affected by crop rotation, conservation practice, and their interaction (Tables 2 and 4). Among crop rotations, the mean values of exchangeable $\mathrm{K}^{+}$ranged from 0.36 to $2.03 \mathrm{cmol}_{\mathrm{c}} / \mathrm{kg}$. The highest and lowest value was recorded under maize-wheat-wheat $\left(2.03 \mathrm{cmol}_{\mathrm{c}} / \mathrm{kg}\right)$ and continuous maize, respectively $\left(0.36 \mathrm{cmol}_{\mathrm{c}} / \mathrm{kg}\right)$ (Table 4$)$. According to Metson [58], recorded values of exchangeable $\mathrm{K}^{+}$were rated as moderate. The relatively high level of exchangeable $\mathrm{K}^{+}$under maize-wheat- wheat rotation might be due to frequent incorporation of wheat straw in to the soil after harvest.

Considering main effects of conservation practice, the mean value of the available potassium under unconserved and conserved farmland was $1.11 \mathrm{cmol}_{\mathrm{c}} / \mathrm{kg}$ and $1.46 \mathrm{cmol}_{\mathrm{C}} /$ $\mathrm{kg}$, respectively (Table 4 ). This might be due to the fact that soil conservation practices which were applied on the land have created conducive environment for the progress of the nutrient availability in the soil. The result was in line with the findings of Worku et al. [59] who stated that available $\mathrm{K}^{+}$ concentrations in farm plots with physical soil and water conservation structures were found to be higher than adjacent unconserved farmlands.

There was a significant $(p<0.05)$ effect of crop rotation and conservation practice and their interaction on exchangeable $\mathrm{Na}^{+}$(Tables 2 and 4). Considering the effects of crop rotations, mean values of exchangeable $\mathrm{Na}^{+}$ranged from 0.45 to $0.68 \mathrm{cmol}_{\mathrm{c}} / \mathrm{kg}$ under continuous maize and maize-pepper-pepper rotations, respectively (Table 4). According to Metson [58], the value of exchangeable $\mathrm{Na}^{+}$ was found at moderate rate.

Considering the main effects of conservation practice, mean value of exchangeable $\mathrm{Na}^{+}$was higher $\left(0.56 \mathrm{cmol}_{\mathrm{c}} / \mathrm{kg}\right)$ under the unconserved farmland than that of unconserved $\left(0.2 \mathrm{cmol}_{\mathrm{c}} / \mathrm{kg}\right)$ (Table 4$)$. The reason might be the relatively high contents of exchangeable $\mathrm{Ca}^{2+}$, since its high content enforces exchangeable $\mathrm{Na}^{+}$to displace and consequently reduce its space on the exchange site of soil particles.

Considering the interaction effect of crop rotation by conservation practice, the mean values of exchangeable $\mathrm{Na}^{+}$ $\left(0.2 \mathrm{cmol}_{\mathrm{c}} / \mathrm{kg}\right)$ in all crop rotations plus conservation practice were relatively lower than farmlands without any conservation measure (Table 2). Therefore, farmland conserved with soil bund seems to have relatively good soil structure and infiltration condition due to lower content of exchangeable $\mathrm{Na}^{+}$than unconserved farmlands.
Generally, considering all crop rotations, the study indicates that maize fields should be rotated with other crops including vegetables and legumes to lessen the ongoing high dependence on mineral fertilizers as described by Traole et al. [60]. It can be suggested that the joint application of organic fertilizer arising from crop residue retention and mineral fertilizer may provide more favorable conditions for the manifestation of the rotation effect.

3.3. Correlation Analysis between Studied Soil Variables. A significant negative correlation $\left(r=-0.1^{*}\right)$ was observed between soil bulk density and clay content. This phenomenon was similar with the finding of Hillel [24] who revealed that for clay soils with good soil structure, there is a greater amount of total pore space because the particles are very small (many small pore spaces fit between them), which causes reduction in bulk density. However, no correlation was observed between soil bulk density and organic matter $\left(r=0.04^{\mathrm{NS}}\right)$ (Table 5). Such result was in contrast with the study conducted by Sakin [61] who identified and showed strong correlation between organic matter and bulk density of soils.

Soil $\mathrm{pH}$ was positively correlated with CEC, available $\mathrm{P}$, and total $\mathrm{N}\left(r=0.48^{* * *}, r=0.61^{* * *}\right.$, and $\left.r=0.49^{* * *}\right)$, respectively, while it was inversely correlated with soil bulk density $\left(r=0.46^{* *}\right)$. The inverse correlation probably suggests washing out of solutes from the farmlands where soil bulk density is higher (Table 5). A significant positive correlation was found between available $\mathrm{P}$ and soil $\mathrm{OM}$ $\left(r=0.42^{* *}\right) \quad$ (Table 5). In contrast to many studies, a nonsignificant positive correlation was observed between soil organic matter content and $\mathrm{pH}\left(r=0.07^{\mathrm{NS}}\right)$. In this study, there was a positive and significant correlation between soil OM and CEC $\left(r=0.61^{* * *}\right)$ (Table 5). CEC also showed positive and significant correlation with clay $\left(r=0.44^{* *}\right)$. This was supported by the study of Gebeyehu [62] who reported that CEC is significantly and positively correlated with clay content. The correlation studies also revealed a significant and positive correlation between $\mathrm{pH}$ and $\mathrm{Ca}\left(r=0.56^{* * *}\right)$.

\section{Conclusions}

Crop rotations where pepper and faba bean were included showed relatively better soil properties status compared to rotations where only cereal crops were involved. Although continuous maize showed good content of available $\mathrm{P}$ and low exchangeable acidity, it will deplete particular nutrients; therefore, maize-pepper-pepper, maize-wheat-faba bean, and maize-faba bean-pepper recorded a slight trend of good values studied soil physicochemical properties compared to other rotations. Therefore, cereals should be rotated with either vegetables or legumes.

Studied soil properties were relatively better on the conserved farm plots than on the nonconserved one. Based on results of the research carried out, the soil of an area which was treated with conservation practice has shown a significant physicochemical property improvement than the soil of the adjacent unconserved land. The $\mathrm{pH}$ of the soil was 


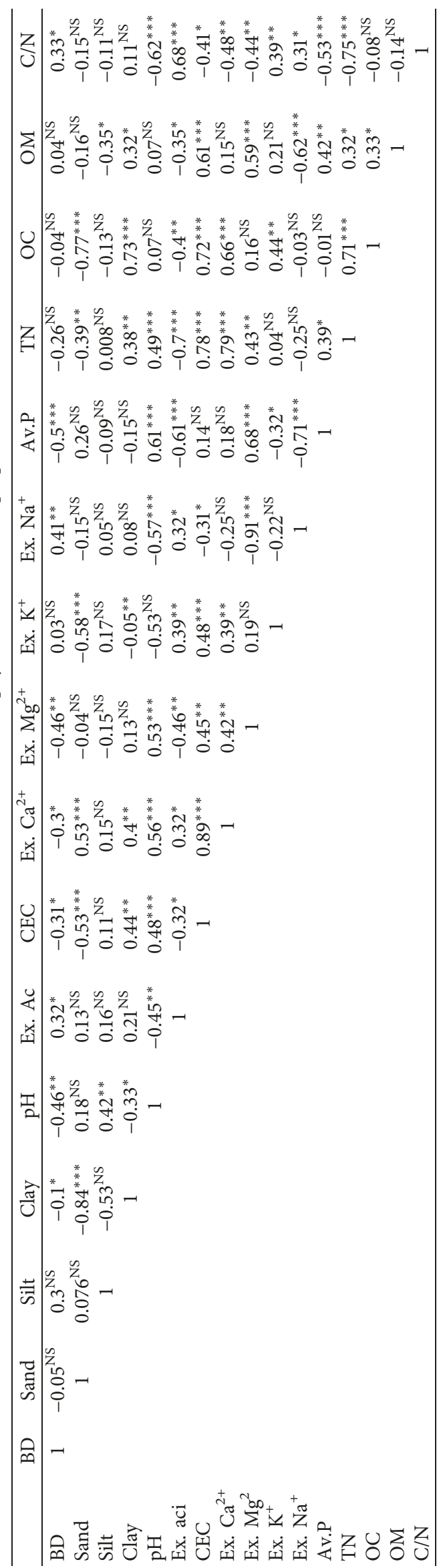


able to increase which in turn facilitates the availability of major nutrients such as available $\mathrm{P}$ in the soil of conserved land. Generally, the major macronutrients required for green plants such as the soil OC, total $\mathrm{N}$, potassium, and $\mathrm{P}$ concentrations in the farmlands which were maintained by soil conservation practice were found somewhat higher than the adjacent unconserved farmlands. This implies that soil and water conservation efforts positively affect soil physicochemical properties, although farmers' future adoption could be challenged by poor perception.

A significant negative correlation was observed between bulk density and clay contents. Soil OM was positively correlated with soil CEC and total nitrogen, while there was no significant correlation observed with bulk density. Even if the study considered short duration of management practices, soil physicochemical property of the study area was strongly influenced by crop rotation and conservation practice.

Since rotation length might be an important factor on soil physicochemical properties change, such type of study should be carried out over a longer period of time. As a result, farmers must be aware that the benefits of rotating crops may be more evident after a considerable long period. Less-acidifying fertilizers and other acidity reclamation activities should be practiced instead of continuous use of DAP since the soil is inherently acidic.

The bunds were only three years old or young; more duration of time will probably lead to greater differences in soil parameter values between soil groups mainly due to prolonged erosion difference between conserved and unconserved lands. Integration of biological and physical conservation measures is vital for better effectiveness and sustainability of soil and water conservation efforts. Furthermore, since this study focused on the analysis of selected physical and chemical soil properties only, further research such as adoption by the community and impacts of soil conservation practice on crop yield was required.

\section{Data Availability}

We applied both primary (actually not to support the findings and conclusion) and secondary data. The primary data that we used to support the findings of this study were new soil samples directly taken from farmers' field in the study area. However, before we went to take the soil samples, we gathered necessary information from key informants to identify representative sampling farm plots as a secondary data. Therefore, the data that support conclusion of the study were accessed from primary data sources (i.e., parameters of soil samples taken from laboratory results).

\section{Conflicts of Interest}

The authors declare that there are no conflicts of interest with regard to the publication of this research paper.

\section{Acknowledgments}

The authors would like to thank the Ethiopian Ministry of Education for providing financial support to accomplish this research work. They extend their special thanks to Mr. Lisanu Getaneh, Debre Berhan Agricultural Research Center, for spending his valuable time to perform the soil analysis.

\section{References}

[1] Z. Gete, K. Menale, J. Pender, and Y. Mahmud, "Stakeholder analysis for sustainable land management (SLM) in Ethiopia: assessment of opportunities, strategic constraints, information needs, and knowledge gaps," Environmental Economics Policy Forum for Ethiopia (EEPFE), pp. 4-91, 2010.

[2] H. Hurni, A. Solomon, B. Amare et al., "Land degradation and sustainable land management in the highlands of Ethiopia," in Global change and sustainable development: A synthesis of regional experiences from research partnerships, $\mathrm{H}$. Hurni and U. Wiesmann, Eds., vol. 5, pp. 187-220, Georaphica Bernensia, Bern, Switzerland, 2010.

[3] T. Girma, "Land degradation: a challenge to Ethiopia," Journal of Environmental Management, vol. 27, no. 6, pp. 815-823, 2001.

[4] D. Lakew, K. Menale, S. Benin, and J. Pende, Land degradation and strategies for sustainable development in the Ethiopian high lands: Amhara Region, Socio-economic and policy Research Working Paper 32, ILRI, Nairobi, Kenya, 2006.

[5] Y. Birru, "Soil and water conservation technologies, transfer and adoption by the smallholder farmers in the Amhara Region," in Proceedings of the Natural Resource Management Conference, Natural Resources Degradation and Environmental Concerns in the Amhara National Regional State: Impact on food security, T. Amede, Ed., Bahir Dar, Ethiopia, July 2002.

[6] Z. Gete, Landscape dynamics and Soil Erosion Process Modeling in the North West Ethiopian Highlands, African Studies Series A16, Ph.D. thesis, p. 202, Geographical Bernensia, Bern, Switzerland, 2000.

[7] E. Elias, Soils of the Ethiopian Highlands: Geomorphology and Properties, ALTERA Wageningen University Research Centre, Wageningen, Netherlands, 2016.

[8] E. Elias, "Farmer's perceptions of soil fertility change and management," SOS-Sahel and Institute for Sustainable Development, Addis Ababa, Ethiopia, 2002.

[9] G. Martin, Soil Conservation Research in Ethiopia, Mountain Research and Development, Addis Ababa, Ethiopia, 1988.

[10] F. Magdoff and H. van Es, Building Soils for Better Crops, Sustainable Agriculture Network, Burlington, VT, USA, 2nd edition, 2000.

[11] L. E. Jackson, T. Rosenstock, M. Thomas, J. Wright, and A. Symstad, "Managed ecosystems: biodiversity and ecosystem functions in landscapes modified by $58 \mathrm{~T}$. Tscharntke et al./Biological Conservation 151 (2012) 53-59 human use," in Biodiversity and Human Impacts, S. Naeem, D. Bunker, A. Hector, M. Loreau, C. Perrings, Eds., Oxford University Press, Oxford, UK, 2009.

[12] R. Blanco and R. Lal, Principles of Soil Conservation and Management, Springer, New York, NY, USA, 2008.

[13] N. Wakene and G. Heluf, "Forms of phosphorus and status of available nutrients under different land use systems of Alfisols in Bako area, Ethiopia," Ethiopian Journal of Natural Resources, vol. 5, no. 1, pp. 17-37, 2003.

[14] Z. Mengesha, S. Mohammed, Y. Mohammed, S. Demeke, A. A. Adem, and L. Mindesilew, "Assessment of soil erosion using RUSLE, GIS and remote sensing in NW Ethiopia," Geoderma Regional, vol. 12, pp. 83-90, 2018. 
[15] R. Margesin and F. Schinner, Manual of Soil Analysis Monitoring and Assessing Soil Bioremediation, Springer Verlag Berlin Heidelberg, Innsbruck, Austria, 2005.

[16] G. W. Gee and J. W. Bauder, "Particle size analysis by hydrometer. A simplified method for routine textural analysis and sensitivity test for measurement parameters," Soil Science Society of America Journal, vol. 43, no. 5, p. 1004, 1979.

[17] USDA (United States Development of Agriculture), "Bulk density, soil quality indicators," May 2011, http://www.usda. gov/sqi/publications/files.

[18] V. C. Jamison, H. A. Weaver, and I. F. Reed, "A hammerdriven soil-core sampler," Soil Science, vol. 69, no. 6, pp. 487-496, 1950.

[19] L. P. Van Reeuwijk, Procedures for Soil Analysis, International Soil Reference and Information Center, Wageningen, Netherlands, 3rd edition, 1992.

[20] A. Walkley and I. A. Black, "An examination of the Degtjareff method for determining soil organic matter, and a proposed modification of the chromic acid titration method," Soil Science, vol. 37, no. 1, pp. 29-38, 1934.

[21] J. Dewis and P. Freitas, Physical and Chemical Methods of Soil and Water Analysis, FAO, Rome, Italy, 1975.

[22] E. O. Mclean, Aluminium in Methods of Soil Analysis, America Science Agronomy, Madison, WI, USA, 1965.

[23] SAS Institute, SAS Software v. 9.3, SAS Institute Inc, Cary, NC, USA, 2012.

[24] D. Hillel, Introduction to Environmental Soil Physics, Elsevier Academic Press, Amsterdam, Netherlands, 2004.

[25] A. D. Halvorson, B. J. Wienhold, and A. L. Black, "Tillage, nitrogen, and cropping system effects on soil carbon sequestration," Soil Science Society of America Journal, vol. 66, no. 3, pp. 906-912, 2002.

[26] D. Mulugeta and S. Stahr, "Assessment of integrated soil and water conservation measures on key soil properties in south Gondar, northwestern Highlands of Ethiopia," Journal of Soil Science and Environmental Management, vol. 1, no. 7, article 164176, 2010.

[27] C. Abay, A. Abdu, and M. Tefera, "Effects of graded stone bunds on selected soil properties in the central highlands of Ethiopia," International Journal of Natural Resource Ecology and Management, vol. 1, no. 2, pp. 42-50, 2016.

[28] Y. Jamala and D. O. Oke, "Soil organic carbon fractions as affected by land use in the Southern Guinea Savanna ecosystem of Adamawa State, Nigeria," Journal of Soil Science and Environmental Management, vol. 4, no. 6, pp. 116-122, 2013.

[29] W. Kebede, M. Awdenegest, and Y. Fantaw, “Farmers' perception of effects of soil and water conservation structures on crop production the case of Bokole watershed, Dawuro zone, southern Ethiopia," M.Sc. thesis, vol. 2, Wondo Genet College of Forestry and Natural Resources, Hawassa University, Awasa, Ethiopia, 2010.

[30] M. Daniel, B. Woldeamlak, and R. Lal, Conservation Effects on Soil Quality and Climate Change, Land Degradation and Development, Wiley Online Library, Hoboken, NJ, USA, 2015.

[31] H. D. Foth and B. G. Ellis, Soil Fertility, John Wiley and Sons, Inc., Ottawa, Canada, 1997.

[32] D.B Fowler and J. Brydon, "No-till winter wheat production on the Canadian practices: timing of nitrogen fertilization," Agronomy Journal, vol. 81, no. 5, pp. 817-825, 1989.

[33] G. Yihenew, "Selected chemical and physical characteristics of soils adet research center and its testing sites in North-western Ethiopia," Ethiopian Journal of Natural Resources, vol. 4, no. 2, pp. 199-215, 2002.
[34] N. R. Hulugalle and T. B. Weaver, "Short-term variations in chemical properties of vertisols as affected by amounts, carbon/nitrogen ratio and nutrient concentration of crops residues," Communication in soil science and plant analysis, vol. 36, pp. 1449-1446, 2005.

[35] R. J. Schaetzl and S. Anderson, Soils: genesis and geomorphology, Cambridge University Press, Cambridge, UK, 2005.

[36] M. Nuruzzaman, H. Lambers, M. D. A. Bolland, and E. J. Veneklaas, "Phosphorus benefits of different legume crops to subsequent wheat grown in different soils of Western Australia," Plant and Soil, vol. 271, no. 1-2, pp. 175-187, 2005.

[37] K. R. Helyar and W. M. Porter, "Soil acidification, its measurement and the process involved," in Soil Acidity and Plant Growth, A. D. Robson, Ed., pp. 61-101, Academic Press Australia, Sydney, Australia, 1989.

[38] T. Birhane, M. Shimbahri, T. Girmay, and A. Fetien, "Effect of integrated soil bunds on key soil properties and soil carbon stock in semi-arid areas of northern Ethiopia," South African Journalof Plant and Soil, vol. 33, no. 4, pp. 297-302, 2016.

[39] S. R. Olsen, V. C. Watenabe, and L. A. Dean, Estimate of Available Phosphorous in Soil by Extraction with Sodium Bicarbonate, USDA Circular. No. 939, 1954.

[40] N. C. Brady, The Nature and Properties of Soils, Macmillan Publishing Company, New York, NY, USA, 10th edition, 1990.

[41] M. Nuruzzaman, H. Lambers, M. D. A. Bolland, and E. J. Veneklaas, "Distribution of carboxylates and acid phosphatase and depletion of different phosphorus fractions in the rhizosphere of a cereal and three grain legumes," Plant Soil, vol. 281, no. 1-2, pp. 109-120, 2006.

[42] K. Osman, Soils: Principles, Properties and Management, Springer Science Business Media, Dordrecht, Netherlands, 2013.

[43] WRB (World Reference Base), World Reference Base for Soil Resources: A framework for International Classification, Correlation and Communication, Food and Agriculture Organization of the United Nations, Rome, Italy, 2006.

[44] P. E. Charman and M. M. Roper, "Soil organic matter," in Soils-their Properties and Management, P. E. V. Charman and B. W. Murphy, Eds., pp. 276-285, Oxford University Press, Melbourne, Australia, 3rd edition, 2007.

[45] D. Shimeles, A. Mohammed, and E. Abayneh, "Characterization and classification of the soils of tenocha-wenchancher micro catchment, Southwest Shewa," M.Sc. thesis, Alemaya University, Dire Dawa, Ethiopia, 2006.

[46] N. Wakene and G. Heluf, "Assessment of important physicochemical properties of Dystric Udalf (Dystric Nitosols) under different management systems in Boko Area, Western Ethiopia," M.Sc. thesis, Alemaya University, Dire Dawa, Ethiopa, 2001.

[47] W. Kebede, M. Awdenegest, and Y. Fantaw, "Effects of level soil bunds and stone bunds on soil properties and its implications for crop production : the case of Bokole watershed, Dawuro zone, Southern Ethiopia," Agricultural Sciences, vol. 2, no. 3, pp. 357-363, 2011.

[48] T. Fairhurst, Handbook for Integrated Soil Fertility Management, Africa soil health consortium, Nairobi, Kenya, 2012.

[49] M. D. McDaniel, L. K. Tiemann, and A. S. Grandy, Does Agriculture Crop Diversity Enhance Soil Microbial Biomass and Organic Matter Dynamics? A Meta-Analysis, University of New Hampshire, Durham, NH, USA, 2013.

[50] Y. Huang, S. Liu, Q. Shen, and L. Zong, "Influence of environment factors on the decomposition of organic carbon in 
agricultural soils," Chinese Journal of Applied Ecology, vol. 13, pp. 709-714, 2002.

[51] S. Jagadamma, R. Lal, R. G. Hoeft, E. D. Nafziger, and E. A. Adee, "Nitrogen fertilization and cropping systems effects on soil organic carbon and total nitrogen pools under chisel-plow tillage in Illinois," Soil and Tillage Research, vol. 95, no. 1-2, pp. 348-356, 2007.

[52] M. I. kpara and A. C. Lgwe, "Soil chemical properties and legume-cereal rotation in an Ultisol in Ksukka, Southeastern Nigeria," African Journal of Biotechnology, vol. 13, no. 23, pp. 2341-2349, 2014.

[53] T. S. Murrell, The Science Behind the Nitrogen Credit for Soybeans, International Plant Nutrition Institute, Peachtree Corners, GA, USA, 2011, http://www.ipni.net.

[54] M. D. McDaniel, A. S. Grandy, L. K. Tiemann, and M. N. Weintraub, "Eleven years of crop diversification alters decomposition dynamics of litter mixtures incubated with soil," Ecosphere, vol. 7, no. 8, article e01426, 2016.

[55] B. Murphy and P. Hazelton, Interpreting Soil Test Results, CSIRO Publisher, Clayton, Australia, 2nd edition, 2007.

[56] K. Fassil and Y. Charles, "Soil fertility status and numass fertilizer recommendation of typic hapluusterts in the northern highlands of Ethiopia," World Applied Sciences Journal, vol. 11, article 14731480, 2009.

[57] B. Behailu, A. Abebayehu, M. Tadesse, and D. Bayu, "The effect of land management practices on soil physical and chemical properties in Gojeb Sub-river Basin of Dedo District, Southwest Ethiopia," Journal of Soil Science and Environmental Management, vol. 7, no. 10, pp. 154-165, 2016.

[58] A. J. Metson, Methods of Chemical Analysis for Soil Survey Samples. Soil Bureau Bulletin No. 12, New Zealand Department of Scientific and Industrial Research. Government Printer, Wellington, New Zealand, 1961.

[59] H. Worku, M. Awdenegest, and Y. Fantaw, "The effects of Fanya juu soil conservation structure on selected soil physical \& chemical properties: the case of goromti watershed, western Ethiopia," Resources and Environment, vol. 2, no. 4, pp. 132-140, 2012.

[60] O. Traore, K. Traole, V. B. Bado, and D. J. P. Lompo, "Crop rotations and soil amendments: impacts on cotton and maize production in cotton based system in Western Burkina Faso," International Journal of Biological and Chemical Sciences, vol. 1, no. 2, pp. 143-150, 2007.

[61] E. Sakin, "Organic carbon organic matter and bulk density relationships in arid-semi arid soils in southeast Anatolia region," African Journal of Biotechnology, vol. 11, no. 6, pp. 1373-1377, 2012.

[62] T. Gebeyehu, "Soil fertility status as influenced by different land uses in Maybar areas of south Wello zone, North Ethiopia," M.Sc. thesis, Haramaya University, Dire Dawa, Ethiopia, 2007. 

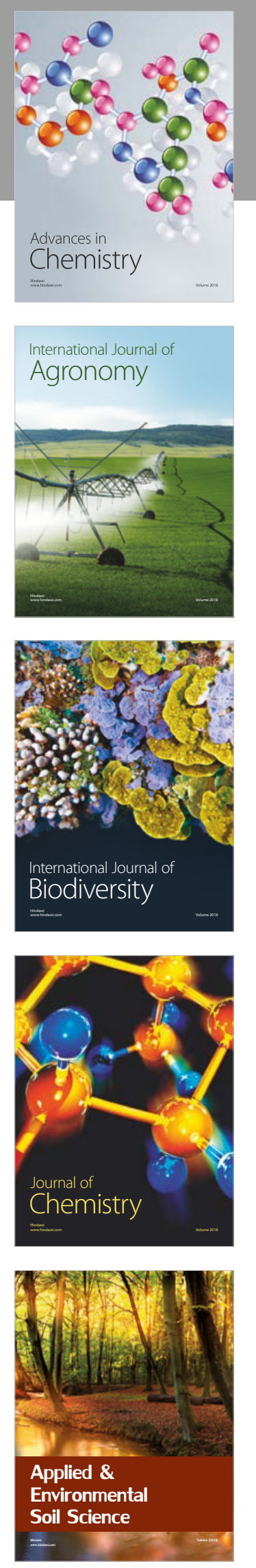

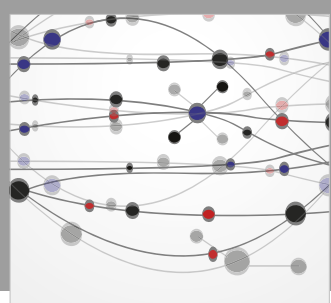

The Scientific World Journal

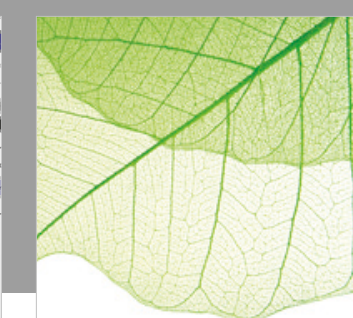

Journal of Botany

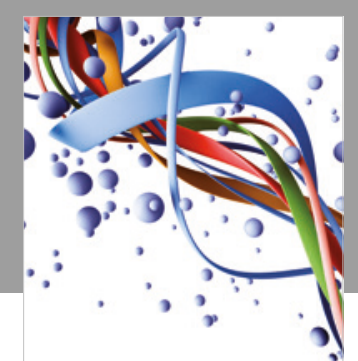

Scientifica

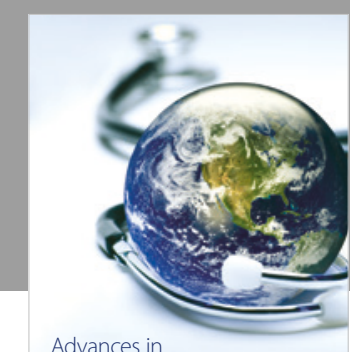

Public Health

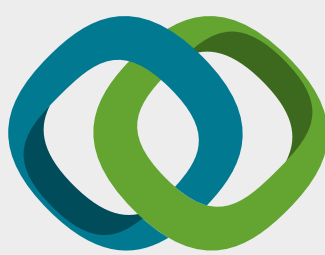

Hindawi

Submit your manuscripts at

www.hindawi.com
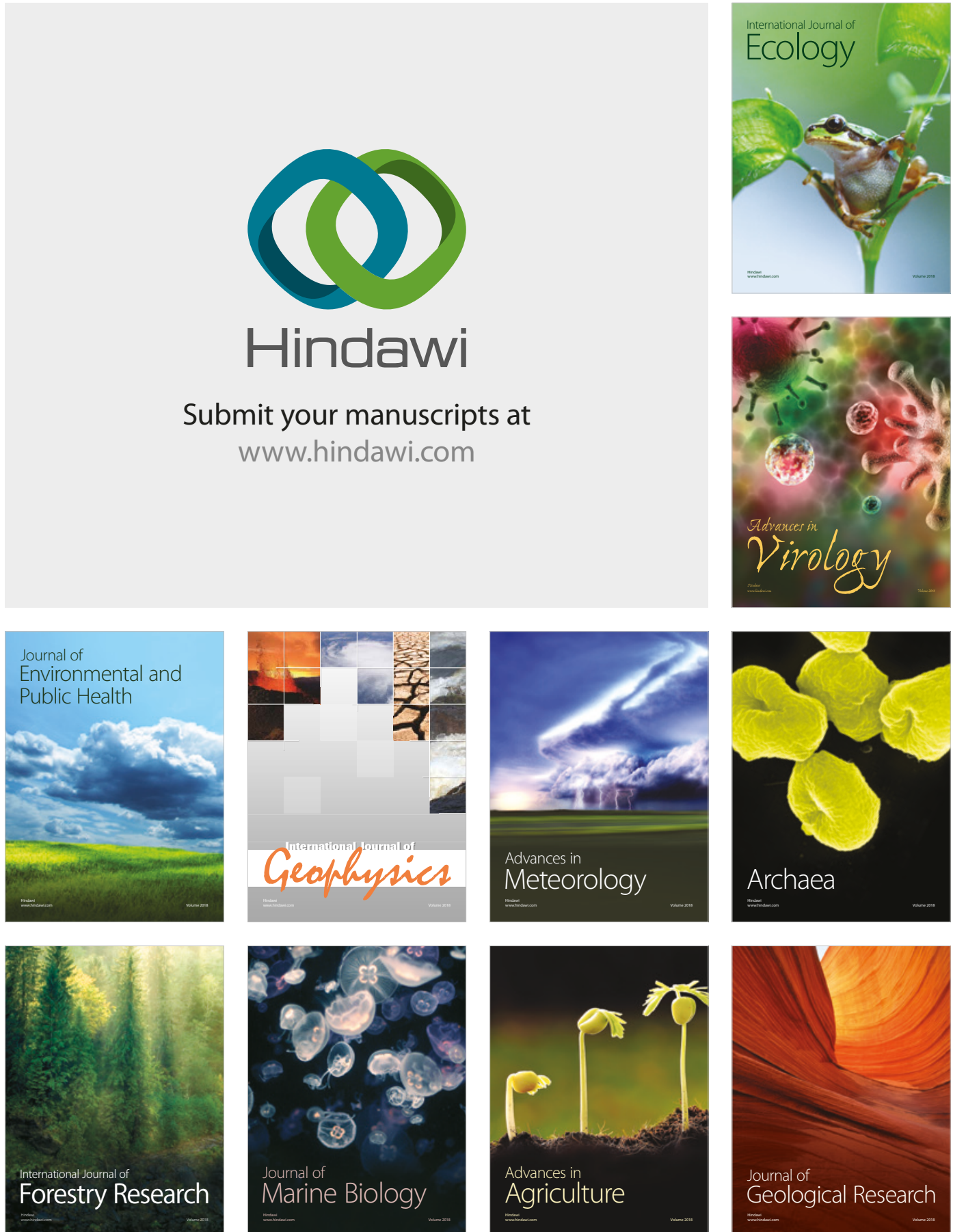

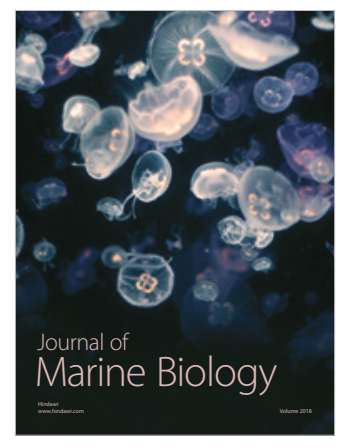

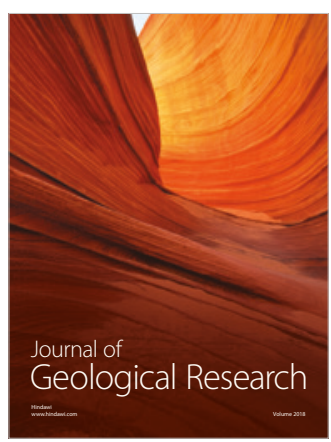

